\title{
Seasonal Variation of Phytoplankton from Parangipettai Coastal Waters, Bay of Bengal, Tamil Nadu, Southeast Coast of India
}

\author{
P. Anantharaman* , A. Hemalatha, M. Suresh \\ Center for Advanced Study in Marine Biology, Faculty of Marine Sciences, Annamalai University, \\ Parangipettai-608 502, India \\ *panantharaman@gmail.com
}

\begin{abstract}
The study of phytoplankton distribution and its seasonal variation was carried out during the April 2014 to March 2015, from the Parangipettai coastal waters, Bay of Bengal, Tamil $\mathrm{Nadu}$, and south-east coast of India. Various physic-chemical parameters were analysed and the correlation with phytoplankton population density was established using Pearson correlation co-efficient. This result showed that the phytoplankton population density was positively correlated with atmospheric temperature, surface water temperature, salinity, $\mathrm{pH}$, chlorophyll ' $\mathrm{a}$ ' primary production $(\mathrm{p}<0.01)$ where negatively correlated with rainfall and nutrients $(p<0.5)$ were detected. Totally 119 species of phytoplankton were recorded which includes 81 species of Bacillariophyceae (Diatoms), 24 species of Dinophyceae (Dinoflagellates), 6 species of Cyanophyceae (Blue-green algae), 7 species of Chlorophyceae (Green algae) and one species of Silicoflagellates (Chrysophyceae) during the study period. Bacillariophyceae species was the dominant followed by Dinophyceae, Chlorophyceae, Cyanophyceae and Silicoflagellates. The lowest phytoplankton diversity in the monsoon period and highest diversity in the post monsoon period was recorded. The Parangipettai coastal waters have been found to be very rich in phytoplankton diversity.
\end{abstract}

Keywords: Phytoplankton, Seasonal variation, Primary production, Nutrients, Bay of Bengal, Hydrological parameters 